\title{
Medicina Interna: ser original es volver a los orígenes
} Internal Medicine: to be original is to return to the origins

\author{
Arturo González Quintela
}

Presidente (casi expresidente) de la SOGAMI

La primera acepción que el Diccionario de la Real Academia Española da para el calificativo original no es la de novedoso sino la de perteneciente o relativo al origen. La Medicina Interna tiene sus orígenes bien definidos y sería un error olvidarlos. Una cosa es adaptarse a los tiempos y a sus necesidades y otra bien distinta es renunciar a los propios principios. La Medicina Interna se ha caracterizado por saber adaptarse a las circunstancias y, muy especialmente, por saber cubrir las necesidades asistenciales cuando a lo largo de la historia han surgido nuevos problemas que estaban fuera del ámbito de una especialidad más concreta, pero sin cambiar la esencia de la profesión. El mismo Diccionario define esencia como aquello que constituye la naturaleza de las cosas, lo permanente, en este caso una forma de atención a las enfermedades del adulto y a las personas que las padecen. En la esencia del internista están las innovaciones originales que propusieron insignes médicos y literatos como Gregorio Marañón (la silla, para escuchar) o Abraham Verghese (la mano, para explorar y para completar, con ese con-tacto, el rito que constituye el acto médico). Es parte de la esencia del internista la visión global de la persona enferma que forma el eslogan de la sociedad nacional en la que los internistas estamos federados. También es esencial al internista el conocimiento profundo y constantemente actualizado de las enfermedades y sus mecanismos sin el cual, sin esa parte de ciencia, todo lo anterior carecería de sentido. Recomiendo al lector que vea la recientemente estrenada película El Médico Atento, en la que participan los doctores Fernando Diz-Lois, Emilio Casariego y Fernando de la Iglesia, todos ellos expresidentes de la SOGAMI, sobre los enfermos, la Medicina (en) General y la Medicina Interna en particular. En ella se desarrollan admirablemente algunas de ideas que estoy intentando plasmar aquí, pero con mucha mejor fortuna. Se podría decir que esos rasgos son esenciales a cualquier disciplina médica, y es verdad, aunque estamos acostumbrados a ver, con demasiada frecuencia, historias clínicas demasiado sucintas (eso sí, muy electrónicas) generadas tras el único con-tacto con una pantalla y un teclado, y seguidas de una solicitud prolija de técnicas diagnósticas y/o de interconsultas que ejemplificarían la razón que tenía Claude Bernard cuando afirmaba que el que no sabe lo que busca, no entiende lo que encuentra. Ser internista es forma de pensar, de actuar y hasta, permítaseme, una forma de ser. Ser internista es independiente de la especialidad que cada uno ostente. No vamos aquí a caer en el error de poner puertas al campo, de intentar fragmentar el conocimiento, o de totemizar y blandir el título de especialista para justificar mezquinas actitudes de posesión cuando se habla de determinadas enfermedades o enfermos. Eso no lo hacen los auténticos especialistas sino algunos listos especiales, como decía Amador Schuller. En este escenario, en los últimos años hemos asistido a un intento de reduccionismo de la Medicina Interna hacia la dedicación exclusiva al paciente crónico complejo. Por supuesto, nadie mejor que los internistas para atender a ese grupo amplio de pacientes cuando están en el hospital y para trabajar en colaboración con Atención Primaria para que no tengan que ingresar en el hospital. Su dimensión en número y en consumo de recursos requiere de los médicos de 


\section{"Ser internista es forma de pensar, de actuar y hasta, permítaseme, una forma de ser. Ser internista es independiente de la especialidad que cada uno ostente".}

más amplios conocimientos y mejores criterios de eficiencia, pero reducir la Medicina Interna a sólo este problema es seguir, permítaseme de nuevo, la senda de los cobardes. El internismo no puede dejar de abarcar todas las enfermedades médicas del adulto. Enlazando con el título, tal reducción y resignación no responde a los orígenes de la Medicina Interna; no es original y el autor de este editorial está convencido que no es buena para los enfermos. Es cierto que una buena parte del trabajo de internista será atender, por un lado, a pacientes que nadie sabe ver y, a la vez, reconozcámoslo todos, a pacientes que nadie quiere ver. Hay que asumirlo sin renunciar a la esencia. Porque ser internista es una vocación. En los tiempos que corren significa ir contracorriente: contra la corriente de que los que suponen que el culto a la súper-especialización, de resultados más pintureros y cortoplacistas, es el futuro. Ser internista supone una labor más abnegada y, en general, menos reconocida. A veces, cuando uno le comenta estas cosas a los potenciales residentes que vienen a informarse sobre la especialidad, le viene a la cabeza el famoso anuncio de Ernest Shackelton, publicado en The Times (1907) a fin de reclutar voluntarios para una de sus expediciones al Polo Sur: "Se buscan hombres para peligroso viaje. Salario reducido. Frío intenso. Largos meses de completa oscuridad. Constante peligro. Dudoso regreso sano y salvo. Honor y reconocimiento en caso de éxito". Y a pesar de ello, muchos y muy buenos residentes siguen eligiendo nuestra especialidad. Sin duda es una exageración, pero prueba que la Medicina Interna es vocacional. El tiempo corre a favor y acabará poniendo las cosas en su sitio: en el estado de máxima entropía, léase el de máxima eficiencia y solidez. Muchos médicos enfermos buscan un internista, por algo será. Esperemos que el llamado Decreto de Troncalidad para la formación de especialistas, si es que llega a aplicarse y a traer alguna buena cosa, sea ésta la mejor formación internística de todos los especialistas. Hay que confiar en que volveremos a los orígenes. Usando la sentencia atribuida a Camilo J. Cela (posiblemente apócrifa), el que resiste, vence; lo peor es resignarse. Nos avala la razón en beneficio de los pacientes y no intereses espurios. El optimismo, dijo también Shackelton, es la verdadera moral y la clave del éxito.
En este escenario, en los últimos años hemos asistido a un intento de reduccionismo de la Medicina Interna hacia la dedicación exclusiva al paciente crónico complejo. 